\title{
RㅋVISIÓN
}

\section{Relevance of nitrate and nitrite in dry-cured ham and their effects on aroma development}

\author{
By Fidel Toldrá, ${ }^{*}$ M-Concepción Aristoy and Mónica Flores
}

\author{
Instituto de Agroquímica y Tecnología de Alimentos (CSIC), \\ PO Box 73, 46100 Burjassot (Valencia), Spain \\ ( ${ }^{*}$ Corresponding author: ftoldra @iata.csic.es)
}

\section{RESUMEN}

Relevancia de nitrato y nitrito en el jamón curado y sus efectos en el desarrollo del aroma.

Las sales sódica y potásica del nitrito (E249 y E250) y del nitrato (E251 y E252) están autorizados para su uso en los productos cárnicos, secos, curados y no tratados por el calor, otros productos cárnicos curados, productos cárnicos enlatados y bacon. El punto esencial en el uso de nitrato y nitrito como conservantes consiste en encontrar un balance entre el aseguramiento de la seguridad microbiológica del jamón y mantener el nivel de nitrosaminas tan bajo como sea posible. Los nitratos y nitritos están autorizados como aditivos en el jamón curado según la Directiva Europea 2006/52/EC de 5 de Julio de 2006 que modificaba la previa Directiva Europea 95/2/EC de aditivos alimentarios distintos a los colorantes y edulcorantes. El efecto del nitrato y su reducción a nitrito para controlar la oxidación de los lípidos durante la maduración del jamón es muy importante para el desarrollo del característico flavor a curado. Se presentan en este manuscrito los principales beneficios y problemas del uso de los nitratos y nitritos en el jamón curado así como sus efectos en el flavor.

PALABRAS CLAVE: Aroma - Flavor - Jamón curado Nitrato - Nitrito - Nitrosaminas.

\section{SUMMARY}

Relevance of nitrate and nitrite in dry-cured ham and their effects on aroma development.

Potassium and sodium salts of nitrite (E 249 and E 250) and nitrate (E 251 and $E$ 252) are authorised for use under certain levels in several foodstuffs such as non-heat-treated, cured and dried meat products, other cured meat products, canned meat products and bacon. The key point in the use of nitrate and nitrite as preservatives is to find a balance between ensuring the microbiological safety of the ham and keeping as low as possible the level of nitrosamines in the final product. Nitrites and nitrates are authorised as additives for dry-cured ham in the Directive 2006/52/EC of 5 July 2006 that modifies previous Council Directive 95/2/EC on food additives other than colours and sweeteners. The effect of nitrate and its reduction to nitrite in controlling the lipid oxidation process during the ham ripening is very important for the development of the characteristic cured flavour. The main benefits and drawbacks of the use of nitrites and nitrates in dry-cured ham and how these levels may affect its flavour are discussed in this manuscript.

KEY-WORDS: Aroma - Dry-cured ham - Flavour Nitrate - Nitrite - Nitrosamines.

\section{INTRODUCTION}

Potassium and Sodium salts of nitrite (E 249 and E 250) and nitrate (E 251 and E 252) are authorised for use under certain levels in several foodstuffs such as non-heat-treated, cured and dried meat products, other cured meat products, canned meat products and bacon. The main reason for such authorisation is based on the proved inhibitory effect of nitrite on Clostridium botulinum. Thus, the ideal situation for the use of nitrate and nitrite as preservatives is to find a balance between the microbiological safety assurance of the food and the reduction in the generation of nitrosamines. However, the regulation of the maximal levels of use in meat products was not so easy in the European Union. Nitrites and nitrates were authorised as additives in Directive 95/2/EC on food additives other than colours and sweeteners but the authorised levels exceeded those maximum levels regulated in Denmark. The Danish Government asked the European Commission in 1996 for an authorisation to keep the restricted nitrite levels in Denmark but this was not authorised by the European Commission in its Decision 1999/830/EC. Thus, the Danish Government denounced this situation to the European Court of Justice (case C3/00). The Court resolved in March 2003 that such Decision should be cancelled and considered that Directive 95/2/EC needed an amendment since it failed to consider the recommendations on maximal levels of nitrite that were called into question by the Scientific Committee on Food (SCF, 1995). Thus, the European Commission asked the European Food Safety Authority for a scientific opinion on 3 questions: i) What was the correlation between ingoing and residual amounts of nitrites and nitrates? 
li) Which was the effect of such amounts against the microbiological risks? and iii) Which were the lowest levels for an effective protection against such microbiological risks, particularly against Clostridium botulinum?

The scientific opinion answering such 3 questions was published on late 2003 (EFSA, 2003). The new Directive 2006/52/EC of 5 July 2006, includes some amendments to the previous Directive 95/2/EC, one of them affecting both sodium or potassium nitrate and nitrite. One of the most important amendments consists in the change of indicative initial amounts by maximum levels to be added that may give a better idea of how it can affect the formation of nitrosamines. Such maximum levels to be added to dry-cured ham are $150 \mathrm{mg} / \mathrm{kg}$ (expressed as sodium nitrite) for either sodium or potassium nitrate or nitrite. The residual levels of either nitrate or nitrite are somehow confusing since they can not really indicate their initial levels nor their degradation during processing. So, a low residual nitrite level in ham might be due to a low addition at the beginning or a long processing that allows an intense degradation. This means that identical residual levels may be found in the product even though the initial amounts may substantially differ. This is the reason why maximum levels of addition are considered in the new Directive. In any case, the new levels are still considered to be too high by the Danish Government who recently raised its concern to the European Commission. The benefits and drawbacks of the use of nitrites and nitrates and how these levels may affect the flavour in such a particular and unique product as is dry-cured ham, will be discussed in this manuscript.

\section{THE NEED FOR NITRATE AND NITRITE IN DRY-CURED HAM}

The addition of nitrates and nitrites to dry-cured ham reinforces the preserving effect of salting by inhibiting the growth of spoilage bacteria, which may cause the deterioration of the ham, but most important that of pathogenic bacteria such as Clostridium botulinum, which causes botulism in humans. This is especially relevant for a product that is consumed without cooking and at room temperature. Dry-cured ham constitutes an entire piece where the addition of the nitrifying agent as a curing salt (mixture of potassium nitrate and sodium chloride) is performed by rubbing on the outer surface. The penetration and diffusion of nitrate through the ham is slow. As long as nitrate gets diffused into the ham, it is converted into nitrite by the microbial enzyme nitrate reductase (Toldrá, 2007). Nitrate does not exert any preservative effect against $C$. Botulinum but constitutes a slow source of nitrite that has a powerful preservative effect, especially at pH 6.0 which is the typical value in drycured ham (Christiansen, 1980). In general, the minimal amount of nitrite for an effective preservative effect ranges from 80 to $100 \mathrm{ppm}$ (Lücke and Roberts, 1993). However, nitrite is immediately reduced to nitric oxide that reacts rapidly with the surrounding proteins including myoglobin. This is why nitrite can not be added to the outer surface; it would react rapidly on the surface without penetration into the ham, thus loosing its preservative effect inside the ham. The use of nitrate as a slow source of nitrite is an excellent way of penetration of nitrite to the inner parts of the ham where higher risks exist (Toldrá, 2004a, 2004b). Furthermore, the slow diffusion of nitrate and its reduction to nitrite allows the formation of nitrosomyoglobin, the typical cured meat pigment that gives ham its characteristic reddish colour (Toldrá, 2002). It is important to control the diffusion rate as it will affect not only the colour but also its uniformity through the entire piece. It must be reminded that some nitrite may react to give nitrate as well as low amounts of gaseous nitrogen (Cassens et al., 1979).

\section{THE FATE OF NITRITE: CONCERNS ABOUT NITROSAMINES GENERATION}

The use of nitrite in cured meats experienced a serious drawback in the late 1960s in the USA due to the $\mathrm{N}$-nitrosamines scare. The presence of some $\mathrm{N}$-nitrosamines, as a consequence of the reaction of nitrite with secondary amines specially in thermally treated cured meats, caused a ban in the USA that was lifted after re-considering maximum amounts to be added (Cassens et al., 1979). A number of $\mathrm{N}$-nitrosamines are potent carcinogenic agents so that its formation must be prevented. A key step consists in the reduction of residual nitrite levels in the meat product. The addition of ascorbic acid ensured the reaction of nitrite to nitric oxide and thus reduced the possibility for such reactions (Cassens, 1997, Toldrá, 2002).

In other cases, the process itself ensures that residual nitrite amounts will be minimal like is the case of dry-cured ham. The nitrosamines formation reaction needs the presence of secondary amines and nitrous acid in its dissociated form. This reaction is very fast at $\mathrm{pH} 3.5$ but decreases as $\mathrm{pH}$ increases (Pegg y Shahidi, 2000). In the case of dry-cured ham, its $\mathrm{pH}$ is near 6.0 or higher, very far of the pKa of nitrous acid ( $\mathrm{pKa}=3.36)$. This means that the level of nitrous acid would be less than $1 \%$ of the nitrite present inside the ham. In fact, the analysis of nitrosamines in dry-cured ham reported very low levels (Demeyer et al., 2000).

\section{DRY CURED HAM FLAVOUR}

Dry-cured ham undergoes a salting and dehydration process that affects the dynamics of water, sodium chloride and also the migration of nitrate and nitrite (Arnau et al., 1995, Toldrá 2004a). However, this process is related to a large variety of meat characteristics such as temperature, $\mathrm{pH}$, structure, presence of intramuscular fat and composition (Gou et al., 2004, Toldrá, 2006a). 
The volatile compounds generated in dry-cured ham contribute to the final aroma depending on several parameters: concentration, odour threshold and the interaction with the food matrix. In nonminced meat products such as dry-cured ham and dry-cured loin the diffusion of volatile compounds is affected by the interactions of volatile compounds and matrix components (Muriel et al., 2004) due to the presence of several barriers, mainly intramuscular fat and connective tissue. It is also essential to consider the medium $\mathrm{pH}$, polarity and molecular weights of volatile compounds because these parameters affect the interaction with the matrix (Seuvre et al., 2002). Studies carried out on the effect of curing agents on the interaction of volatile compounds with the protein matrix of drycured ham did not reveal any significant effect of nitrate or nitrite on such types of interactions (Gianelli, et al., 2005, Flores et al., 2007). The mechanisms involved in the generation of dry-cured ham flavour have been studied (Toldrá et al., 2007, Toldrá and Flores, 1998, Toldrá, 1998) as well as the volatile compounds present in its headspace (Gianelli et al., 2002). The composition of the volatile compounds responsible for the aroma of dry-cured ham depends on the processing but also the analytical methodology used for its analysis, such as solvent extraction, vacuum distillation, dynamic headspace, etc., making their study and comparison very difficult. Therefore, the volatile compounds present in the headspace have been analyzed at temperatures between 30 to $40{ }^{\circ} \mathrm{C}$ in French (Berdagué et al., 1991, Buscailhon et al., 1993), Parma (Barbieri et al., 1992, Bolzoni et al., 1996), Iberian (López, et al., 1992, Sabio et al., 1998, Ruiz et al., 1999) and Serrano dry-cured hams (Flores et al., 1997) in order to mimic the release of volatile compounds during mastication. Highest temperature has been used (around $60{ }^{\circ} \mathrm{C}$ ) with other volatile extraction techniques such as vacuum distillation (Dirinck et al., 1997) and super critical carbon dioxide (Timon et al., 1998).

The first works on Country-style hams (Lillard and Ayres, 1969, Ockerman et al., 1964) reported several carbonyls, alcohols and esters compounds. Later, several investigations identified and quantified the volatile compounds in French (Berdagué et al., 1991, Buscailhon et al., 1993), Italian (Barbieri et al., 1992, Careri et al., 1993, Hinrichsen and Pedersen, 1995 and Bolzoni et al., 1996), and Spanish (García et al., 1991, López et al., 1992) dry-cured hams and they were able to detect around 261 compounds. The vacuum distillation technique used for the analysis produced a higher abundance of carboxylic acids, lactones and aliphatic hydrocarbons than in the case of dynamic headspace.

\section{REACTIONS IN THE GENERATION OF AROMA VOLATILE COMPOUNDS}

The volatile compounds present in dry-cured ham have been extensively studied (Berdagué et al.,
1991, Bolzoni et al., 1996, Buscailhon et al., 1993, Flores et al., 1997, Ruiz et al., 1998, 1999). The identified volatile compounds belong to the following classes: alkanes, alkenes, aldehydes, ketones, alcohols, aromatic hydrocarbons, carboxylic acids, esters, terpenes, sulfur compounds, furans, pyrazines, amines and chloride compounds. During the processing of dry-cured ham, different pathways have been proposed as responsible for their generation. However, the impact of an odour component on the final dry-cured ham flavour depends on odour threshold, concentration, solubility in water or fat, and temperature as reported elsewhere (Flores et al., 1998). The main routes of formation are as follows:

The oxidative decomposition of lipids has been reported to produce a high variety of compounds like aliphatic hydrocarbons, alcohols and aldehydes (Shahidi et al., 1986). Aldehydes have shown to be contributors to the loss of desirable flavour in meats because of their low flavour thresholds and high rate of formation during lipid oxidation (Frankel, 1984).

The amino acid degradation reactions produced branched aldehydes and alcohols such as 2-methyl propanal, 2-methyl butanal, and 3-methyl butanal that are generated from Strecker degradation of the amino acids, valine, isoleucine and leucine, respectively (Forss, 1972). The intense proteolytic activity in drycured hams results in an increased concentration of free amino acids (Toldrá \& Flores, 1998) that serve as a pool for the Strecker type reactions.

Sulfide compounds are formed from the sulfur containing amino acids, such as methionine, cysteine, and cystine via Strecker degradations to thiols (Shahidi et al., 1986). These sulfur compounds are among the important contributors to meat flavour due to their low odour threshold (Chang and Petersen, 1977, Drumm and Spanier, 1991).

Esters are formed from the interaction of free fatty acids and alcohols generated by lipid oxidation in the intramuscular tissue (Baines and Mlokiewicz, 1984, Shahidi et al., 1986). Baines and Mlokiewicz, (1984) reported that esters from C1-C10 acids tend to impart a fruity sweet note to pork meat whereas esters derived from long chain fatty acids give a more fatty flavor character as found in beef. Esters compounds were detected in higher amounts in Italian dry-cured ham (Barbieri et al., 1992) than in French hams (Berdagué et al., 1991, Buscailhon et al., 1993) and Spanish hams (Flores et al., 1998, Pérez-Juan, 2006). The presence of the large ester abundance in Italian (Parma) ham was attributed to the lack of nitrate use in its processing (Parolari, 1996) while it is usually added to Spanish and French dry-cured hams. It was proposed that the inhibitory effect of nitrate/nitrite on lipid oxidation could be the reason for the lower concentration of esters in Spanish and French dry-cured hams (Flores et al., 1998).

However, the study of volatile compounds in meat products was usually based on their abundance without considering their contribution to the final aroma. Therefore in the last years the 
aroma impact compounds in meat products were studied using olfactometry techniques (Toldrá and Flores, 2004). Using these techniques, several sulfur compounds such as 2-methyl-3-furanthiol, methanothiol, hydrogen sulfide were detected as important contributors to dry-cured aroma (Carrapiso et al., 2002a,b). These sulfur compounds are generated in very low proportions in dry-cured ham but they have very low thresholds (Shahidi et al., 1986). In addition, aldehydes produced from amino acid degradation and lipid oxidation like 2-methyl-propanal, 3-methyl-butanal, hexanal, (E)-2-Hexenal and (Z)-3-hexenal are important contributors to the aroma as several ketones like 2-heptanone and 1-penten-3-one that also come from lipid oxidation. However, only one ester compound, ethyl-2-methylbutanoate, was described as an aroma contributor.

\section{EFFECT OF NITRITE ON FLAVOUR}

It is well known that oxidative rancidity is delayed in nitrite cured meats. The exact mechanisms for this antioxidant action is still under discussion since four different mechanisms have been proposed (Pegg and Shahidi, 2000): i) Reaction of nitrite with heme pigments forming a stable complex, ii) action in tissue membranes by stabilizing its unsaturated lipids, iii) action of nitrite as a metal chelator and iv) the formation of nitroso compounds that can act as radical scavengers.

Nitrite is reported to produce a characteristic cured meat flavour even though the chemical changes involved, probably due to its antioxidant activity, are not well understood. The differences in volatile composition of uncured and cured cooked pork was analysed and reported in the 1990s (Ramarathnam et al., 1991, 1993). These authors determined the effect of curing, essentially the addition of nitrite, in the development of cured cooked flavour. The main differences between both types of products were detected in the content of carbonyl compounds. These authors indicated that carbonyl compounds are essential contributors to the flavour of uncured meat. However, they could not elucidate the compounds responsible of the cured meat flavour. In summary, the addition of nitrate and nitrite is essential for flavour development as nitrite reacts with a large number of meat components and affects the reactions occurring in the meat product during processing. Therefore, it is necessary to know the processing conditions and additives added to the meat product to elucidate the compounds responsible for the flavour in the final product. So, the effects of nitrate and nitrite on the sensory quality of dry-cured lacón, a typical product in northwestern of Spain, have been recently studied by Lorenzo et al $(2008 a, b)$. The protein degradation and also the fat acidity values, as an index of fat hydrolysis, occurring during the manufacture of dry-cured lacón, were reported to be only moderate when compared with ham dry-curing process, and additives did not significantly affect both processes; proteolysis and lipolysis. Neither the free fatty acid content nor their profile were significantly affected by the use of such additives (Lorenzo et al., 2008a). Nevertheless, sensory analysis comparing dry-cured lacón with and without such additives, revealed (Lorenzo et al., $2008 \mathrm{~b}$ ) that the use of additives seems to improve the colour (higher intensity of the red colour and brightness in the lean and lower dryness) and the odour (intensity and typical odour of cured meats attributes) of the final product confirming the importance of nitrite. On the other hand, a recent study comparing 5 different commercial brands of socalled uncured hams with the nitrite-/added control ham did not find differences in sensory attributes (Sindelar et al., 2007).

Finally, the effect of nitrate and nitrite has been assayed against main muscle proteolytic and lipolytic enzymes that play an important role in the processing of dry-cured ham and its flavour development (Toldrá and Flores, 1998, Toldrá, $1998,2006 b)$. These curing agents have not shown a relevant effect on such enzymes under the assayed conditions (Toldrá, 2006a).

\section{CONCLUSIONS}

Thus, from the wide variety of compounds identified in dry-cured ham, the impact of compounds derived from the lipid oxidation process (aldehydes and methyl ketones) appear to be essential for the aroma of the product. Therefore, the effect of nitrate and its reduction to nitrite in controlling the lipid oxidation process during the ham ripening is very important for the development of the characteristic cured flavour. In addition, the low ester abundance in nitrate/nitrite treated dry cured hams in comparison to Parma hams (no nitrate/nitrite added) is another evidence of the nitrite effect on aroma generation. In summary, further research is needed to elucidate the contribution of nitrite and nitrate to flavour development in dry cured ham by identifying the responsible volatile compounds. Moreover, due to the use of nitrate in long ripening processes, it is essential to determine its rate of conversion into nitrite and its effect on flavour development.

\section{ACKNOWLEDGEMENT}

Grant AGL2007-65379-C02-01/ALI from the Spanish Ministry of Science and Innovation and FEDER funds is fully acknowledged.

\section{REFERENCES}

Arnau J, Guerrero L, Casademont G, Gou P. 1995. Physical and chemical changes in different zones of normal and PSE dry cured ham during processing. Food Chem.52, 63-69. 
Baines DA; Mlotkiewicz JA. 1984. The chemistry of meat flavor, in Bailey AJ (Ed.); Recent Advances in the Chemistry of Meat, 119-164, The Royal Society of Chemistry, Burlington House, London.

Barbieri G; Bolzoni L; Parolari G; Virgili R; Buttini R; Careri M; Mangia A. 1992. Flavor compounds of dry-cured ham. J. Agric. and Food Chem. 40, 2389-2394.

Berdagué JL, Denoyer C, LeQueré JL, Semon E. 1991. Volatile Components of Dry-Cured Ham. J. Sci. Food Agric. 39, 1257-1261.

Bolzoni L, Barbieri G, Virgili R. 1996. Changes in volatile compounds of parma ham during maturation. Meat Science, 43, 301-310.

Buscailhon S, Berdagué JL, Monin G. 1993. Time related changes in volatile compounds of lean tissue during processing of French Dry-Cured Ham. J. Sci. Food Agric. 63, 69-75.

Careri M, Mangia A, Barbieri G, Bolzoni L, Virgili R, Parolari G. 1993.Sensory property relationships to chemical data of Italian type dry-cured ham. J. Food Sci. 58, 968-972.

Carrapiso Al, Jurado A, Timon ML, García C. 2002a. Odor-active compounds of Iberian hams with different aroma characteristics. J. Agric. Food Chem. 50, 64536458.

Carrapiso Al, Ventanas J, García C. 2002b. Characterization of the most odor-active compounds of Iberian ham headspace. J. Agric. Food Chem. 50, 1996-2000.

Cassens RG, Greaser ML, Ito T, Lee M. 1979. Reactions of nitrite in meat. Food Technol. 33, 46-57.

Cassens RG. 1997. Composition and safety of cured meats in the USA. Food Chem. 59, 561-566.

Chang SS, Petersen RJ. 1977. Recent developments in the flavor of meat. J. Food Sci. 42, 298-305.

Christiansen LN. 1980. Factors influencing botulinal inhibition by nitrite. Food Technol. 34, 237.

Demeyer DI, Raemakers M, Rizzo A, Holck A, De Smedt A, Ten Brink B, Hagen B, Montel C, Zanardi E, Murbrek E, Leroy F, Vanderdriessche F, Lorentsen K, Venema K, Sunesen L, Stahnke L, De Vuyst L, Talon R, Chizzolini R, Eerola S. 2000. Control of bioflavor and safety in fermented sausages: first results of a European project. Food Res. Int. 33, 171-180.

Dirinck P, Van Opstaele F, Vandendriessche F. 1997. Flavour differences between northern and southern European cured hams. Food Chem. 59, 511-521.

Drumm TD, Spanier AM. 1991. Changes in the content of lipid autoxidation and sulfur-containing compounds in cooked beef during storage. J. Agric. Food Chem. 39, 336-343

EFSA. 2003. Opinion of the Scientific Panel on biological hazards on the request from the Commission related to the Effect of Nitrites/Nitrates on the Microbiological Safety of Meat Products. The EFSA Journal 14, 1-31.

Flores M, Grimm CC, Toldrá F, Spanier AM. 1997. Correlations of sensory and volatile compounds of Spanish "Serrano" dry-cured ham as a function of two processing times. J. Agric. Food Chem. 45, 2178-2186.

Flores M., Spanier AM, Toldrá F. 1998. Flavour analysis of dry-cured ham, in Shahidi $F$ (Ed.), Flavor of meat, meat products and seafood. $2^{\text {nd }}$ edición, 320-339, Blackie Academic \& Professional, Chapman \& Hall, London.

Flores M, Gianelli MP, Pérez-Juan M, Toldrá F. 2007. Headspace concentration of selected dry-cured aroma compounds in model systems as affected by curing agents. Food Chem. 102, 488-493.
Forss DA. 1972. Odor and flavor compounds from lipids. Progr. Chem. Fats other Lipids. 13, 181-258.

Frankel EN. 1984. Recent advances in the chemistry of rancidity of fats, in Bailey AJ (Ed.); Recent Advances in the Chemistry of Meat, 87-118, The Royal Society of Chemistry, Burlington House, London.

García C; Berdagué JL, Antequera T; López-bote C; Córdoba JJ; Ventanas J. 1991. Volatile components of dry-cured Iberian ham. Food Chem.41, 23-32.

Gianelli MP, Flores M, Toldrá F. 2002. Analysis of volatile compounds of dry-cured ham using different solidphase microextraction (SPME) fiber coatings. J. Sci. Food Agric.82, 1703-1709.

Gianelli MP, Flores M, Toldrá F. 2005. Interactions of soluble peptides and proteins from skeletal muscle with volatile compounds as affected by curing agents. J. Agric. Food Chem.53, 1670-1677.

Gou P, Comaposada J, Arnau J. 2004. Moisture diffusivity in the lean tissue of dry-cured ham at different process times. Meat Science 67, 203-209.

Hinrichsen LL; Pedersen SB. 1995. Relationship among flavor, volatile compounds, chemical changes, and microflora in Italian-type dry-cured ham during processing. J. Agric. Food Chem. 43, 2932-2940.

Lillard DA, Ayres JC. 1969. Flavor compounds in countrycured hams. Food Technol. 23, 117-120.

Lopez MO; De la Hoz L; Cambero MI; Gallardo E; Reglero G; Ordoñez JA. 1992. Volatile compounds of dry hams from Iberian pigs. Meat Sci. 31, 267-277.

Lorenzo JM, Fontan MCG, Franco I, Carballo J. 2008a. Biochemical characteristics of dry-cured lacon (a Spanish traditional meat product) throughout the manufacture, and sensorial properties of the final product. Effect of some additives. Food Control 19, 1148-1158.

Lorenzo JM, Fontan MCG, Franco I, Carballo J. 2008b. Proteolytic and lipolytic modifications during the manufacture of dry-cured lacon, a Spanish traditional meat product: Effect of some additives. Food Chem. 110, 137-149.

Lücke FK, Roberts TA. 1993. Control in meat and meat products, in: Hauschild AHW, Dodds KL (Eds), Clostridium botulinum ecology and control in foods. 177-207,Marcel Dekker Inc., New York, USA.

Muriel E, Ruiz J, Martin D, Petron MJ, Antequera T. 2004. Physico-chemical and sensory characteristics of drycured loin from different Iberian pig lines. Food Sci.Technol. Int. 10, 117-123.

Ockerman HW, Blumer TN, Craig HB. 1964. Volatile chemical compounds in dry-cured hams. J. Food Sci. 29, 123-129.

Parolari G. 1996. Review: Achivements, needs and perspectives in dry-cured ham technology: the example of Parma ham. Food Sci. Technol. Int. 2, 69-78.

Pegg RB, Shahidi F. 2000. Nitrite curing of meat. WileyBlackwell, Ames, lowa, USA.

Pérez-Juan M, Flores M, Toldrá F. 2006. Generation of volatile flavour compounds as affected by the chemical composition of different dry-cured ham sections. Eur. Food Res Technol. 222, 658-666.

Ramarathnam N, Rubin LJ, Diosady LL. 1991. Studies on meat flavor. 1. Qualitative and quantitative differences in uncured and cured pork. J. Agric. Food Chem. 39, 344-350.

Ramarathnam N, Rubin LJ, Diosady LL. 1993. Studies on meat flavor. 3. A novel method for trapping volatile components from uncured and cured pork. J. Agric. Food Chem. 41, 933-938. 
Ruiz J, Cava R, Ventanas J, Jensen MT. 1998. Headspace solid phase microextraction for the analysis of volatiles in a meat product: Dry-cured Iberian ham. J. Agric. Food Chem. 46, 4688-4694.

Ruiz J, Ventanas J, Cava R, Andrés A, García C. 1999. Volatile compounds of dry-cured Iberian ham as affected by the length of the curing process. Meat Sci., 52, 19-27.

Sabio E, Vidal-Aragón MC, Bernalte MJ, Gata JL. 1998. Volatile compounds present in six types of dry-cured ham from south European countries. Food Chem. 61, 493-503.

Seuvre AM, Espinosa-Diaz MA, Voilley A. 2002. Transfer of aroma compounds through the lipidic-aqueous interface in a complex system. J. Agric. Food Chem. 50, 1106-1110.

Shahidi F; Rubin LJ; D'Souza, LA. 1986. Meat flavor volatiles: A review of the composition, techniques of analysis, and sensory evaluations. Crit. Reviews Food Sci. and Nutri. 24, 141-243.

Sindelar JJ, Cordray JC, Sebranek JG, Love JA. 2007. Investigating quality atytributes and consumer acceptance of uncured, no nitrate/nitrite added commercial hams, bacons and frankfurters. J. Food Sci. 72, s511-s559.

Timón ML, Ventanas J, Martín L, Tejeda JF, García C. 1998. Volatile Compounds in Supercritical Carbon Dioxide Extracts of Iberian Ham. J. Agric. Food Chem. 46, 5143-5150.

Toldrá F, Flores M, Sanz Y. 1997. Dry-cured ham flavour: Enzymatic generation and process influence. Food Chem. 59, 523-530.

Toldrá F, Flores M. 1998. The role of muscle proteases and lipases in flavor development during the processing of dry-cured ham. Crit. Reviews Food Sci. Nutri. 38, 331-352.
Toldrá F. 1998. Proteolysis and lipolysis in flavour development of dry-cured meat products. Meat Sci. 49, S101-S110.

Toldrá F. 2002. Dry-cured meat products. Wiley-Blackwell, Ames, lowa, USA.

Toldrá F. 2004a. Curing: Dry, in Jensen W, Devine C, Dikemann M (Eds.), Encyclopedia of Meat Sciences, 360-365, Elsevier Science Ltd., London, UK.

Toldrá F. 2004b. Dry-cured ham. in: Hui YH, Goddik LM, Josephsen J, Stanfield PS, Hansen AS, Nip WK, Toldrá $\mathrm{F}$ (Eds.), Handbook of food and beverage fermentation technology, 369-384, Marcel-Dekker Inc., New York, USA.

Toldrá F, Flores M. 2004. Analysis of meat quality factors, in Nollet L (Ed.), Handbook of Food Analysis, $2^{\text {nd }}$ edition, 1961-1977, Marcel-Dekker Inc., New York, USA.

Toldrá F. 2006a. Dry-cured ham, in: Hui YH, Castell-Perez E, Cunha LM, Guerrero-Legarreta I, Liang HH, Lo YM, Marshall DL, Nip WK, Shahidi F, Sherkat F, Winger RJ, Yam KL (Eds.), Handbook of Food Science, Technology and Engineering, vol 4, 164-1 to 164-11, CRC Press, Boca Raton, FL, USA.

Toldrá F. 2006b. The role of muscle enzymes in dry-cured meat products with different drying conditions. Trends Food Sci.Technol. 17, 164-168.

Toldrá F. 2007. Ham, in: Hui YH, Chandan R, Clark S, Cross N, Dobbs J, Hurst WJ, Nollet LML, Shimoni E, N Sinha, Smith EB, Surapat S, Titchenal A, Toldrá F (Eds.), Handbook of Food Product Manufacturing,Vol 2, 231-247, John Wiley Interscience, NY, USA. 